\title{
Effect of different levels and particle sizes of perlite on carcass characteristics and tibia ash of broiler chicks
}

\author{
Hamid Reza Ebadi Azar ${ }^{1 \star}$, Kambiz Nazer Adl', Yahya Ebrahim Nezhad ${ }^{1}$ and Mohammad \\ Moghaddam ${ }^{2}$
}

\author{
${ }^{1}$ Department of Animal Science, Islamic Azad University, Shabestar Branch, Shabestar, Iran. \\ ${ }^{2}$ Department of Agronomy and Plant Breeding, Faculty of Agriculture, University of Tabriz, Tabriz, Iran.
}

Accepted 27 June, 2011

\begin{abstract}
The objective of this study was to investigate the effects of different levels and particle sizes of perlite in broiler chicks' diets on carcass characteristics and tibia ash. For the stated purpose, 308 Ross broiler chicks of 280-day-old were allocated to seven treatments and four replications in a factorial experiment on the basis of randomized complete block design. One factor consisted of two particle sizes of perlite (1.5 and $3 \mathrm{~mm}$ ) and the other factor included three levels of perlite (1, 3 and $5 \%$ of diet). A control treatment with no perlite was also included in the experiment. Based on the results obtained, the perlite levels and particle sizes did not affect the weight percentage of net carcass, pectoral, thighs, heart, liver, spleen and abdominal fat, however, they influenced the gizzard weight significantly $(P<0.05)$. Furthermore, no significant difference was observed for tibia ash among the experimental treatments. It seemed that perlite did not have any major impact on the investigated characteristics.
\end{abstract}

Key words: Perlite, aluminosilicate, particle size, carcass, tibia ash.

\section{INTRODUCTION}

Perlite is an aluminosilicate volcanic rock which is made of rapid solidified acidic magma. The volume of perlite rock increases from 4 to 20 times at temperature of about 860 to $1200^{\circ} \mathrm{C}$ and produces expanded perlite (Anonymous, 2006). As shown in Figure 1, expanded perlite has porous texture which gives it unique characteristics. Perlite chemical composition is given in Table 1.

One of the perlite applications is its usage in livestock and poultry feed industry. However, reports in this research area are scarce. A few studies on the use of aluminum silicates, such as zeolite, bentonite and clinoptilolite, in feeding livestock and poultry have been reported. Due to the similarity of these materials with perlite, it is expected that perlite has similar effect on broiler chick's feeding (Tatar, 2006). Minato (1968) observed an increase in feed efficiency and health of broiler chicks due to the utilization of dietary zeolite.

*Corresponding author. E-mail: hrebadi@yahoo.com.
Dzhen and Sakhalinian (1987) examining the role of zeolite in broiler chicks diet, reported a raise in daily weight gain and meat yield. According to the studies of some other researchers, dietary intake of aluminosilicates significantly increased the bone development that could be caused by higher absorption of calcium or lower availability of phosphorus or both (Watkins et al., 1989; Ingram et al., 1989; Watkins and Southern, 1991). Palic et al. (1993) investigated the effect of zeolite in diet and concluded that this substance improved the final weight and feed conversion ratio and decreased the mortality of broiler chicks. Furthermore, some researchers reported that carcass characteristics such as relative weight of liver and spleen of broilers were increased by using aluminosilicates in dietary rations (Yalcin et al., 1995; and Miazzo et al., 2005). On the other hand, Mirabdolbagi et al. $(2007 a, b)$ reported that pectoral, thigh, abdominal fat, spleen and tibia ash of broiler chicks were not affected by aluminosilicates used in diets.

The aim of this study was to investigate the effects of different levels and particle sizes of perlite in diet on carcass characteristics and tibia ash of broiler chickens. 

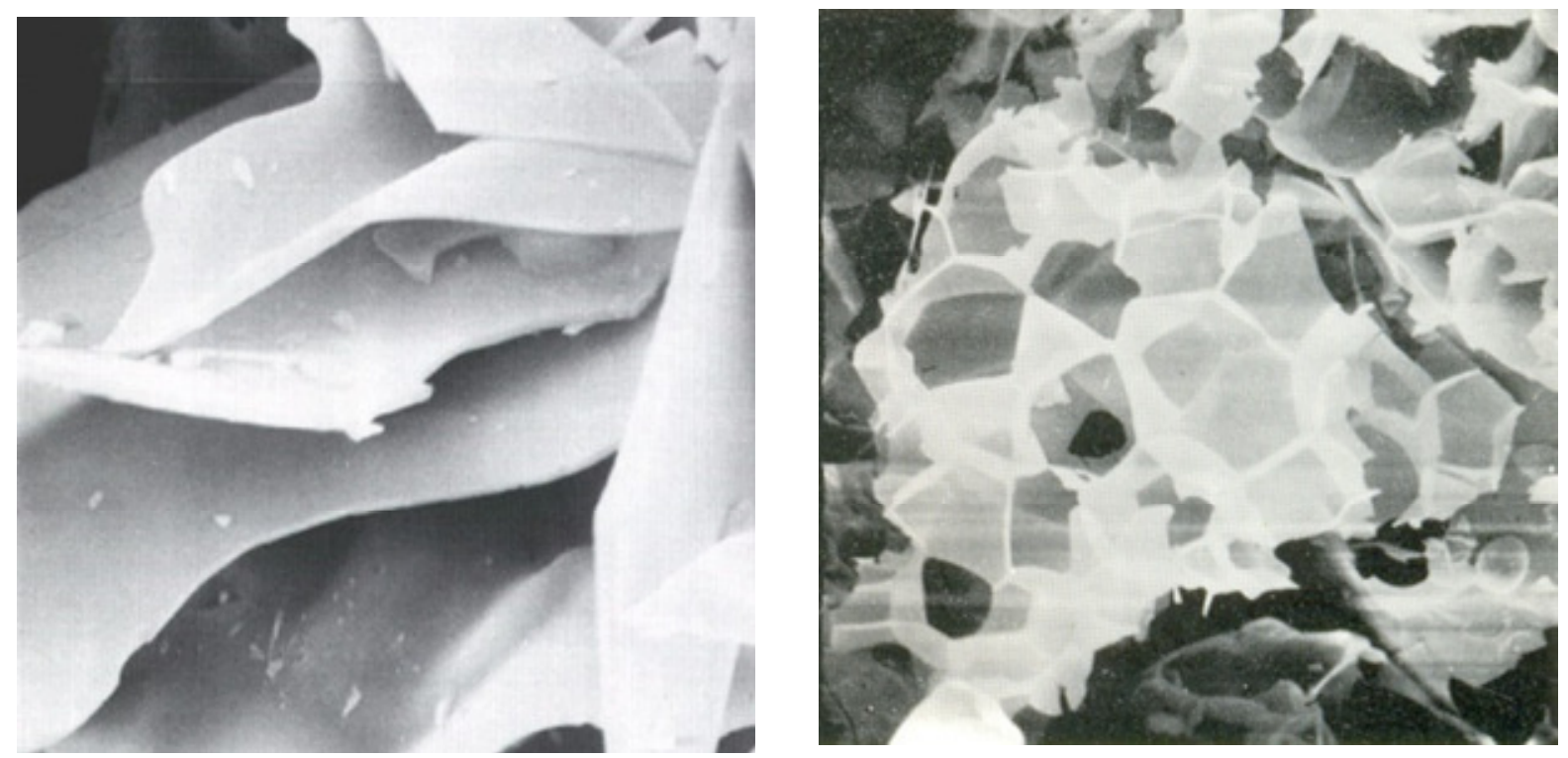

Figure 1. Microscopic image of the porous texture of perlite (Anonymous, 1993).

Table 1. Chemical composition of perlite.

\begin{tabular}{lc}
\hline Element & Percent \\
\hline $\mathrm{Si}$ & 33.8 \\
$\mathrm{Al}$ & 7.2 \\
$\mathrm{~K}$ & 3.5 \\
$\mathrm{Na}$ & 3.4 \\
$\mathrm{Fe}$ & 0.6 \\
$\mathrm{Ca}$ & 0.6 \\
$\mathrm{Mg}$ & 0.2 \\
$\mathrm{Trace}$ elements & 0.2 \\
$\mathrm{O}_{2}$ & 47.5 \\
Water & 3.0 \\
\hline
\end{tabular}

Anonymous (1993).

\section{Materials and methods}

In this study, 308 Ross broiler chicks of 280-day-old were allocated to seven treatments and four replications in a factorial experiment on the basis of randomized complete block design. Factors were particle size (1.5 and $3 \mathrm{~mm}$ ) and levels (1,3 and $5 \%$ of diet) of perlite. In addition, a treatment with no perlite was included as the control group. Therefore, the experiment consisted of seven treatments. In order to control the possible variation in environmental factors, such as light and ventilation along the experimental site, the site was divided into four complete blocks and the treatments were randomly allocated in each block. The perlite used in this study was extracted from perlite mines of East Azerbaijan province and its purity was proved by chemical analysis based on the recommendations of the relevant factory.

At day 49 , carcass characteristics were assessed using Scholty Sek technique and the remained tibia ash were measured through the burning method by removing the organic material (Khosroshahi Asl, 1997). Energy and protein content of the diets were identical and they only differed in the levels and particle sizes of perlite.
Nutritional requirements of broiler chickens during the growing periods were balanced according to the recommendations of the National Research Council (NRC,1994) and using the user friendly feed formulation done again (UFFDA) software. The diets used in this research and supplied nutrients in starter, grower and finisher periods are given in Table 2. Analysis of variance and mean comparisons by Duncan's new multiple range test $(5 \%$ probability level) were performed using MSTATC 11 and SPSS 16.0 software. Effect of perlite on performance traits such as body weight, body weight gain and feed conversion rate were reported elsewhere (Ebadi Azar et al., Journal of Animal Science, Islamic Azad University, Shabestar Branch; In print).

\section{Results and Discussion}

No significant differences were observed among the experimental treatments for net carcass weight percentage (Table 3). Yalcin et al. (1995) also found that 
Table 2. Composition of the experimental diets.

\begin{tabular}{|c|c|c|c|c|c|c|c|c|c|c|c|c|}
\hline \multirow{2}{*}{$\frac{\text { Ingredient }}{\text { Corn }}$} & \multicolumn{4}{|c|}{ Starter diet (days 1 to 21 ) } & \multicolumn{4}{|c|}{ Grower diet (days 22 to 42) } & \multicolumn{4}{|c|}{ Finisher diet (days 43 to 49 ) } \\
\hline & 43.91 & 44.26 & 46.86 & 49.36 & 54.74 & 54.92 & 54.30 & 56.72 & 57.87 & 57.44 & 56.37 & 59.49 \\
\hline Soybean meal $(44 \% \mathrm{P})$ & 33.93 & 34.58 & 35.91 & 37.31 & 25.66 & 26.25 & 27.42 & 28.96 & 21.16 & 21.72 & 22.86 & 24.32 \\
\hline Wheat & 7.00 & 7.00 & 7.00 & 0.00 & 5.50 & 5.50 & 4.00 & 1.00 & 5.00 & 4.50 & 4.50 & 2.00 \\
\hline Barley & 3.00 & 3.00 & 0.06 & 0.00 & 5.00 & 4.00 & 2.50 & 1.20 & 6.00 & 5.00 & 5.00 & 1.17 \\
\hline Wheat bran & 5.03 & 3.02 & 0.00 & 0.00 & 4.00 & 3.00 & 2.50 & 0.50 & 4.97 & 4.84 & 2.25 & 1.50 \\
\hline Sunflower oil & 3.50 & 3.50 & 3.50 & 4.65 & 1.75 & 1.98 & 2.92 & 3.25 & 2.00 & 2.50 & 3.00 & 3.50 \\
\hline Calcium carbonate & 1.33 & 1.31 & 1.29 & 1.28 & 1.27 & 1.25 & 1.24 & 1.22 & 1.20 & 1.19 & 1.17 & 1.16 \\
\hline Dicalcium phosphate & 1.27 & 1.30 & 1.34 & 1.35 & 1.12 & 1.14 & 1.16 & 1.19 & 0.94 & 0.94 & 0.98 & 1.00 \\
\hline Salt & 0.25 & 0.25 & 0.25 & 0.25 & 0.25 & 0.25 & 0.25 & 0.25 & 0.25 & 0.25 & 0.25 & 0.25 \\
\hline Mineral premix ${ }^{*}$ & 0.25 & 0.25 & 0.25 & 0.25 & 0.25 & 0.25 & 0.25 & 0.25 & 0.25 & 0.25 & 0.25 & 0.25 \\
\hline Vitamin premix ${ }^{\dagger}$ & 0.25 & 0.25 & 0.25 & 0.25 & 0.25 & 0.25 & 0.25 & 0.25 & 0.25 & 0.25 & 0.25 & 0.25 \\
\hline DL-Methionine & 0.15 & 0.15 & 0.15 & 0.15 & 0.06 & 0.06 & 0.06 & 0.06 & 0.01 & 0.01 & 0.01 & 0.01 \\
\hline Vitamin E & 0.10 & 0.10 & 0.10 & 0.10 & 0.10 & 0.10 & 0.10 & 0.10 & 0.10 & 0.10 & 0.10 & 0.10 \\
\hline Cocsidio acetate & 0.05 & 0.05 & 0.05 & 0.05 & 0.05 & 0.05 & 0.05 & 0.05 & 0.00 & 0.00 & 0.00 & 0.00 \\
\hline Perlite & 0.00 & 1.00 & 3.00 & 5.00 & 0.00 & 1.00 & 3.00 & 5.00 & 0.00 & 1.00 & 3.00 & 5.00 \\
\hline \multicolumn{13}{|c|}{ Calculated nutritive values } \\
\hline $\mathrm{ME}, \mathrm{kcal} / \mathrm{kg}$ & 2900 & 2900 & 2900 & 2900 & 2900 & 2900 & 2900 & 2900 & 2950 & 2950 & 2950 & 2950 \\
\hline $\mathrm{CP}(\%)$ & 20.85 & 20.85 & 20.85 & 20.85 & 18.125 & 18.125 & 18.125 & 18.125 & 16.594 & 16.594 & 16.594 & 16.594 \\
\hline P:ME ratio & 139.09 & 139.09 & 139.09 & 139.09 & 160.00 & 160.00 & 160.00 & 160.00 & 177.78 & 177.78 & 177.78 & 177.78 \\
\hline $\mathrm{Ca}(\%)$ & 0.89 & 0.89 & 0.89 & 0.89 & 0.818 & 0.818 & 0.816 & 0.816 & 0.74 & 0.74 & 0.74 & 0.74 \\
\hline Available P (\%) & 0.40 & 0.40 & 0.40 & 0.40 & 0.362 & 0.362 & 0.362 & 0.362 & 0.322 & 0.322 & 0.322 & 0.322 \\
\hline $\mathrm{Cl}(\%)$ & 0.20 & 0.20 & 0.19 & 0.19 & 0.197 & 0.195 & 0.193 & 0.190 & 0.19 & 0.19 & 0.19 & 0.19 \\
\hline K (\%) & 0.92 & 0.91 & 0.89 & 0.90 & 0.77 & 0.77 & 0.77 & 0.77 & 0.70 & 0.70 & 0.70 & 0.70 \\
\hline $\mathrm{Na}(\%)$ & 0.13 & 0.13 & 0.13 & 0.13 & 0.126 & 0.125 & 0.124 & 0.122 & 0.125 & 0.125 & 0.123 & 0.122 \\
\hline Lysine (\%) & 1.16 & 1.17 & 1.19 & 1.22 & 0.95 & 0.95 & 0.97 & 0.98 & 0.83 & 0.84 & 0.85 & 0.87 \\
\hline Methionine (\%) & 0.45 & 0.44 & 0.45 & 0.45 & 0.35 & 0.35 & 0.35 & 0.36 & 0.34 & 0.34 & 0.34 & 0.34 \\
\hline $\begin{array}{l}\text { Methionine + Cysteine } \\
(\%)\end{array}$ & 0.82 & 0.81 & 0.81 & 0.82 & 0.67 & 0.67 & 0.67 & 0.68 & 0.66 & 0.66 & 0.67 & 0.67 \\
\hline
\end{tabular}

*Supply per kg food: $333 \mathrm{mg} \mathrm{MnO} ; 220 \mathrm{mg} \mathrm{ZnSO} 47 \mathrm{H}_{2} \mathrm{O} ; 450 \mathrm{mg}$ ferric citrate; 35 mg CuSO $44 \mathrm{H}_{2} \mathrm{O} ; 2$ mg KIO ${ }_{3} ; 1 \mathrm{mg} \mathrm{CoSO}_{4} 8 \mathrm{H}_{2} \mathrm{O} ; 0.35 \mathrm{mg} \mathrm{Na}_{2} \mathrm{SeO}_{3}{ }^{\dagger}{ }^{\dagger} \mathrm{Supply} \mathrm{per}$ $\mathrm{kg}$ food: $900 \mathrm{\mu g}$ retinol; $15 \mathrm{\mu g}$ cholecalciferol; $2 \mathrm{mg}$ menadione sodium bisulphate; $2 \mathrm{mg}$ thiamine; $5 \mathrm{mg}$ riboflavin; $15 \mathrm{mg}$ calcium pantothenate; $30 \mathrm{mg}$ niacin: 3.5 $\mathrm{mg}$ pyridoxine; $0.2 \mathrm{mg}$ biotin; $0.6 \mathrm{mg}$ folic acid; $0.02 \mathrm{mg}$ vitamin $\mathrm{B}_{12} ; 200 \mathrm{mg}$ choline chloride. 
Table 3. Mean values of carcass characteristics and tibia ash in 49-day old broiler chickens fed on diets containing different levels and particles sizes of perlite.

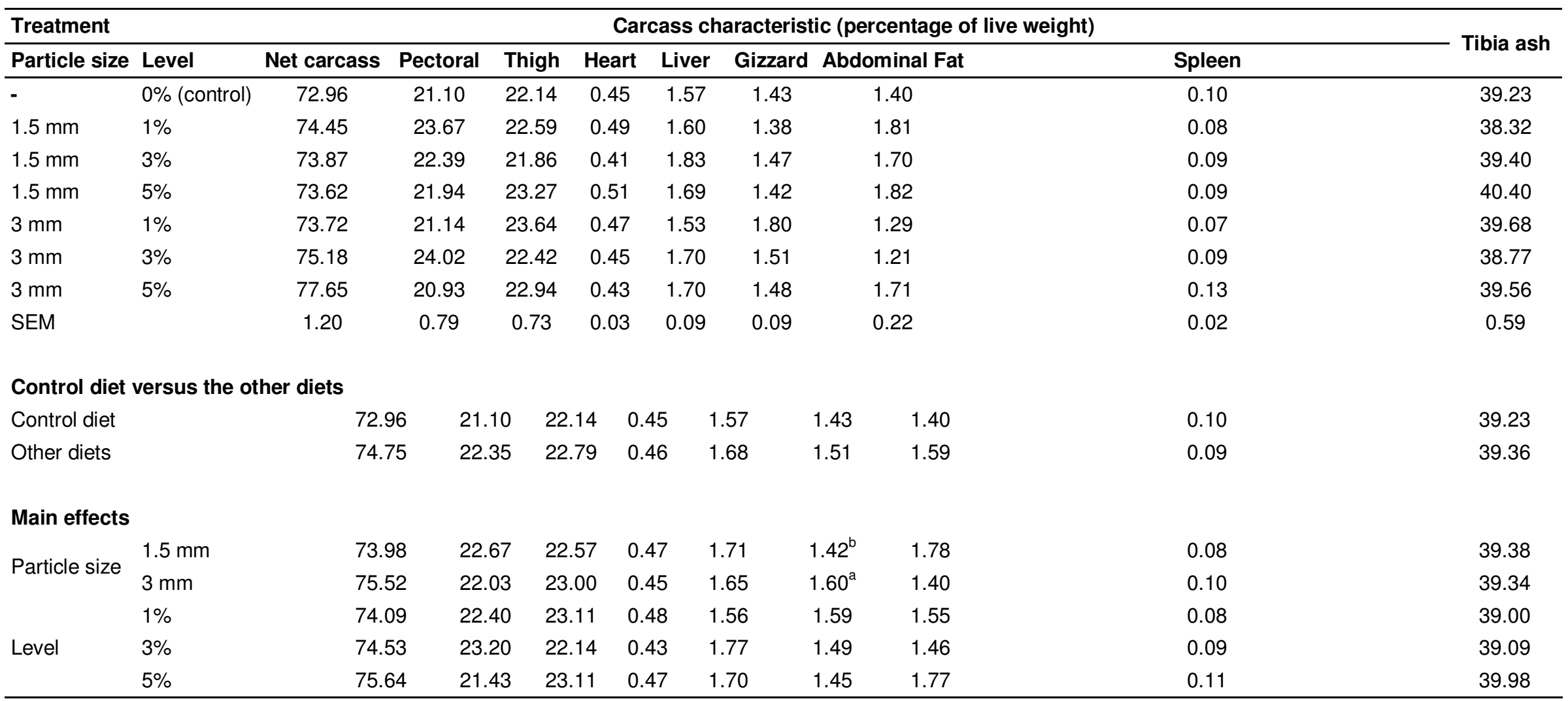

In each column and for each factor, the numbers which are not marked with the same characters, are significantly different $(P<0.05)$.

addng zeolite to diet did not affect the net carcass weight percentage of broiler chicks. Lotfollahian et al. (2004) using two types of aluminosilicates reported that net carcass weight percentage was not influenced by the investigated substances. Furthermore, Tatar (2006) comparing the effect of perlite and zeolite on carcass of broilers showed that adding 2.5 and $5 \%$ of these materials to diet did not cause any significant difference on net carcass weight. Based on the results shown in
Table 3, it can be clearly seen that there was no difference among treatments in terms of pectoral and thigh weight percentage. Tatar (2006) reported that using perlite did not influence the weight of pectoral and thigh of broiler chicks. Some other researchers, also showed that adding 1.5 to $5 \%$ of aluminosilicates to broilers dietary rations had no major effect on weight percentage of the pectoral and thigh (Mirabdolbagi et al., 2007a, 2007b). In another study, howerver, Palic et al. (1993) concluded that using dietary zeolite increased the meat production of broilers and consequently yielded higher pectoral and thigh weight percentage which can be due to the effect of aluminosilicates in improving the gastrointestinal tract health and feed conversion ratio. As shown in Table 3, differences among experimental groups were not significant for heart and liver weight. These findings correspond with the results of Santurio et al. (1999) who concluded 
that using bentonite in broilers diets did not affect the heart and liver weight. However, in another study, examining the use of bentonite in diets contaminated with mycotoxins, there was reduced damage to the liver tissue and decrease in weight (Miazzo et al., 2005). This seems to be due to aluminosilicates' role in capturing heavy cations and radioactive elements in their structural pores and canals, thereby decreasing the poisoning effects of mycotoxins (Mirabdolbagi et al., 2007b). Additionally, the effect of aluminosilicates in forming stable complexes with aflatoxins and decreasing their availability seems to be another factor in the detoxification of gastrointestinal tract and subsequently liver weight reduction (Kubena and Harvey, 1993). The controversy between the results of this study and the earlier mentioned reports may be due to the lack of toxins in this research.

Weight percentage of gizzard was significantly affected by the particle size of perlite (Table 3 ). The perlite with the particle size of $3 \mathrm{~mm}$ caused the highest gizzard weight. This was possibly due to the effect of larger particles of food remaining and staying longer in gizzard, increasing its wall muscle activity and subsequently making it bulkier (Kilburn and Edwards, 2004). Nir et al. (1994) and Huang et al. (2006) examining the broilers carcass characteristics, stated that weight and volume of gizzard had a direct relation with particle size of the diet.

There was no significant difference among the treatments in terms of abdominal fat weight (Table 3 ). Tatar (2006) investigating the effect of perlite on weight percentage of abdominal fat, also showed that aluminosilicate did not cause any difference between the experimental groups. Other studies reported that adding 1.5 to $5 \%$ of aluminosilicates to the rations did not have major influence on the abdominal fat of broilers (Yalcin et al., 1995; Mirabdolbagi et al., 2007a, b).

Based on the findings of this study, different levels and particle sizes of perlite did not affect the spleen weight of broilers (Table 3). Mirabdolbagi et al. (2007a) reported that using 2.5 to $5 \%$ of clinoptilolite in broilers diets did not have any effect on their spleen weight. Nevertheless, Miazzo et al. (2005) found that bentonite in diets contaminated with aflatoxins, decreased the weight percentage of spleen which is due to the effect of aluminosilicates in blocking aflatoxins. The data in Table 3 showed that there was no significant variance regarding tibia ash among groups, which is consistent with the observations of Mirabdolbagi et al. (2007a). Based on the reports of these researchers, using clinoptilolite in diets did not affect the tibia ash of broilers. On the other hand, Yalcin et al. (1995) declared that adding zeolite to broilers rations caused an increase in tibia ash, which can possibly be as a result of aluminosilicates and more calcium absorption, regarding their high capacity in bivalent cations exchange.

In conclusion, the results of this research showed that although larger particles of perlite caused a raise in gizzard weight, different levels and particle sizes of perlite had no major impact on broilers carcass improvement.

\section{REFERENCES}

Anonymous (1993). Perlite applications in filtration. Cooperative of Azerbaijan regional mineral mines.

Anonymous (2006). Conversation with Iranian and Asia perlite association managers. J. Cultivation Industry World. pp. 33: p. 3.

Dzhen S, Sakhalinian D (1987). Zeolite in the feed of broilers. Poult. Abstracts 014-01196.

Huang DS, Li DF, Xing JJ, Ma YX, Li ZJ, Lv SQ (2006). Effects of feed particle size and feed form on survival of Salmonella typhimurium in the alimentary tract and cecal $S$. typhimurium reduction in growing broilers. J. Poult. Sci. 85: 831-836.

Ingram DR, Aguillard CD, Laurent SM (1989). Bone development and breaking strength as influenced by sodium zeolite A. J. Poult. Sci. 68(Suppl): 71-77.

Khosroshahi A (1997). Food analytical chemistry (Translation). Urmia University Publications. pp. 137-141.

Kilburn J, Edwards HM (2004). The effect of particle size of commercial soybean meal on performance and nutrient utilization of broiler chicks. J. Poult. Sci. 83: 428-432.

Kubena LF, Harvey RB (1993). Effect of hydrated sodium calcium aluminosilicate on aflatoxicosis in broiler chicks. J. Poult. Sci. 72 651-657.

Lotfollahian H, Shariatmadari F, Shiva Azad M, and Mirhadi A (2004). Effects of using two types of natural zeolite in diet on blood biochemical factors, the relative weight of internal organs, and broiler performance. J. Res. Construct. 64: 18-34.

Miazzo R, Peraltla MF, Magnole C, Salvano M, Ferrero S Chiacchiera SM (2005). Efficiency of sodium bentonite as a detoxifier of broiler feed contaminated with aflatoxin and fumonisin. J. Poult. Sci. 84: 1-8.

Minato H (1968). Characteristics and uses of natural zeolites. Koatsugasu, 5: 536-547.

Mirabdolbagi J, Lotfollahian H, Hoseini S, Irajian G (2007a). Effects of bentonite in broiler nutrition. Proceedings of second congress of animal science and seafood, Anim. Sci. Res. Ins. Karaj. pp. 950-953.

Mirabdolbagi J, Lotfollahian $H$, Shariatmadari F, Shourmasti DK (2007b). Effects of inactivated and activated clinoptilolite on broiler performance. Proceedings of second congress of animal science and seafood, Anim. Sci. Res. Ins., Karaj. pp. 942-946.

National Research Council (1994). Nutrition requirements of poultries. National Academy Press, Washington, D.C.

Nir I, Hillel R, Shefet G, Nitsan Z (1994). Effect of grain particle size on performance. 2. Grain texture interactions. J. Poult. Sci. 73(6): 781 791

Palic T, Vukicevic O, Resanovic R, Rajic I (1993). Possible applications of natural zeolites in poultry production. Poultry Abstracts 021002130.

Santurio JM, Mallmann CA, Rosa AP, Appel G, Heer A, Dageforde S. Bottcher $M$ (1999). Effect of sodium bentonite on the performance and blood variables of broiler chickens intoxicated with aflatoxins. Brit. Poult. Sci. 40(1): 115-119.

Tatar A (2006). Comparison of the effects of different levels of perlite and zeolite on broiler chicks performance. MSc thesis on animal science. Department of Animal Science, University of Agricultural Science and Natural Resources of Gorgan, IRAN

Watkins KL, Southern LL (1991). Effect of dietary sodium zeolites A and graded levels of calcium on growth, plasma and tibia characteristics of chicks. J. Poult. Sci. 70: 2295-2303.

Watkins KL, Vagnoni DB, Southern LL (1989). Effect of dietary sodium zeolite A and excess calcium on growth and tibia calcium and phosphorus concentration in uninfected and eimeria acervulinainfected chicks. J. Poult. Sci. 68: 1236-1240.

Yalcin S, Bilgili SE, McDaniel GR (1995). Sodium zeolite A: influence on broiler carcass yields and tibia characteristics. Appl. Poult. Sci. 4: 61 68. 